\title{
PENGENDALIAN GAS BROWN PADA ELEKTROLISER UNTUK MENINGKATKAN UNJUK KERJA MOTOR BAKAR
}

\author{
Sri Paryanto Mursid ${ }^{1}$, Zaki Hamzah ${ }^{2}$ \\ Jurusan Teknik Konversi Energi Politeknik Negeri Bandung \\ Email: sp_mursid@yahoo.co.id; hamzah_dzack@yahoo.co.id
}

\begin{abstract}
Abstrak
Gas Brown (gas HHO) adalah campuran gas-gas hasil elektrolisa air menjadi hidrogen, uap air dan oksigen. Pemanfaatan gas HHO untuk penghematan bahan bakar pada motor bakar (mesin bensin atau mesin diesel) sudah banyak diterapkan. Umumnya menerapkan suplai laju gas HHO yang konstan Laju produksi gas HHO yang konstan dapat membuat unjuk kerja motor bakar berkurang, karena terbentuknya uap air pada saat putaran mesin rendah dan kekurangan gas HHO pada putaran tinggi. Agar kerja motor bakar optimal maka perlu diatur laju suplai gas HHO sesuai dengan kebutuhan saja. Untuk itu, pada tulisan ini dibuat alat pengendali laju produksi gas HHO berdasarkan kecepatan putaran mesin untuk aplikasi penambahan bahan bakar pada mesin bensin. Dari hasil penelitian diperoleh laju produksi gas $\mathrm{HHO}$ pada kecepatan putaran mesin $3000 \mathrm{rpm}$ sebesar $1,4 \mathrm{~mL} / \mathrm{s}$ dan pada $1000 \mathrm{rpm}$ sebesar 0,72 $\mathrm{mL} / \mathrm{s}$. Diharapkan gas HHO dapat meningkatkan unjuk kerja mesin bensin dan dapat mengurangi emisi gas buang.
\end{abstract}

Kata kunci :gas HHO, elektroliser, pengendali, putaran mesin, mesin bensin. 


\section{PENDAHULUAN}

Energi adalah masalah yang tetap dominan sampai saat ini. Problematika energi adalah kebutuhan energi yang terus meningkat, sedangkan produksi energi terus menurun. Problematika energi yang kini menjadi isu paling menarik adalah ketergantungan masyarakat dunia yang semakin tinggi akan energi fosil, khususnya minyak bumi, sedangkan cadangannya semakin berkurang, maka orang berusaha menggunakan energi minyak bumi sehemat mungkin dan mencari sumber energi lain sebagai pengganti minyak bumi.

Peranan minyak bumi sebagai energi primer di Indonesia masih cukup dominan yaitu, 46\%. Bila ditinjau dari sisi cadangan minyak, Indonesia masih memiliki cadangan minyak sebesar 3,7 milyar barel atau rasio cadangan per produksi adalah 10,2 tahun yang artinya cadangan minyak Indonesia akan habis dalam waktu 10,2 tahun mendatang, dengan catatan produksi dan konsumsi minyak bumi konstan (sumber: BP). Pada kenyataanya, produksi dan konsumsi minyak bumi tidak berimbang, produksi yang turun dan konsumsi yang meningkat.

Karena hal-hal tersebut, maka masyarakat harus berusaha untuk memanfaatkan energi sebaik dan sehemat mungkin. Menurut peraturan pemerintah Republik Indonesia Nomor 70 tahun 2009 tentang Konservasi, dinyatakan bahwa energi harus digunakan secara hemat, rasional dan bijaksana. Salah satu pemanfaatan sumber energi secara hemat adalah dengan menerapkan teknologi energi efisien.

Salah satu inovasi penghematan energi adalah penambahan gas brown (HHO) pada mesin kendaraan. Selain untuk penghematan energi, gas ini bermanfaat juga untuk menurunkan emisi gas buang, karena dapat menurunkan kandungan $\mathrm{HC}$ dan $\mathrm{CO}^{[1]}$, dan mendinginkan mesin karena gas $\mathrm{HHO}$ mengandung uap air ${ }^{[2]}$.

Eko (2007) memanfaatkan sistem gas HHO untuk diterapkan pada mesin spark ignition dengan laju produksi gas HHO yang konstan. Penambahan sistem produksi gas $\mathrm{HHO}$ pada mesin yang menghasilkan keluaran konstan bisa dikatakan tidak efektif, karena hanya cocok dengan putaran mesin tertentu saja. Pada putaran mesin yang lebih tinggi, mesin kekurangan suplai gas HHO dan sebaliknya, kelebihan suplai gas $\mathrm{HHO}$ akan menyebabkan korosi pada mesin dan juga pemborosan energi pada reaksi elektroliser. Untuk itu diperlukan pengaturan laju produksi gas HHO pada sistem elektroliser yang disesuaikan dengan kebutuhan mesin.

\section{METODOLOGI}

\section{Proses Pemecahan Hidrogen}

Proses pemecahan hidrogen dilakukan dengan menggunakan "potensial tegangan" untuk menstimulasi molekul air sehingga dapat menghasilkan energi yang diinginkan. Potensial tegangan adalah gaya listrik yang terdapat di dalam sebuah rangkaian listrik. Arus listrik dialirkan ke air melalui anoda dan katoda sehingga ion dan molekul air saling tarik menarik ketika saat terjadi reaksi. Dalam proses ini terjadi saling tabrakan antara kedua partikel tersebut, sehingga menyebabkan terjadi gelembung-gelembung udara. Elektron akan bergerak ke arah elektroda positif dan begitu pula dengan partikel positif akan bergerak menuju ke arah elektroda negatif. Orbital elektron akan berubah dari bulat ke bentuk elips, dikopel dengan efek pulsa dan menyebabkan terjadinya electric stress pada ikatan kovalen antara atom oksigen dan hidrogen sehingga terpisah ${ }^{[6]}$. Untuk 
melakukan hal tersebut, dibutuhkan energi yang besar, yaitu dengan menyediakan arus yang besar pula.

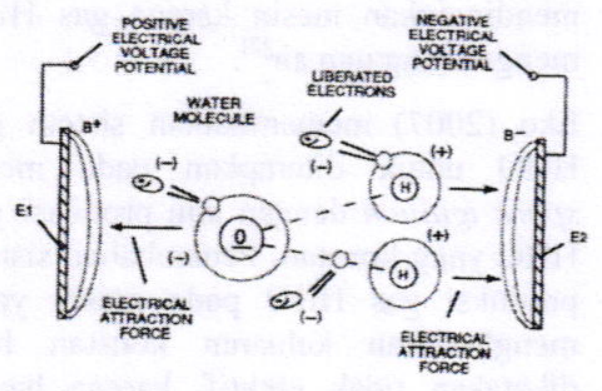

Gambar 1. Proses Elektrolisis

\section{Proses Elektrolisis}

Dalam elektrolisis air, secara umum hidrogen dihasilkan dengan mengelektrolisis larutan campuran air destilasi dengan alkali, dalam hal ini adalah $\mathrm{KOH}$. Reaksi yang terjadi adalah sebagai berikut :

$\mathrm{H}_{2} \mathrm{O}+$ energi listrik $\rightarrow \mathrm{H}_{2}+\frac{1}{2} \mathrm{O}_{2}$

Pada reaksi tersebut, energi listrik diubah menjadi energi kimia yang tersimpan dalam hidrogen. Reaksi yang terjadi pada elektroda adalah sebagai berikut :

\begin{tabular}{llll} 
Larutan & $\mathrm{KOH} \longrightarrow \mathrm{K}^{+}+\mathrm{OH}^{-}$ & $\times 4$ \\
Katoda & $\mathrm{K}^{+}+\mathrm{e}$ & $\mathrm{K}$ & $\times 4$ \\
& $2 \mathrm{~K}+2 \mathrm{H}_{2} \mathrm{O} \longrightarrow 2 \mathrm{KOH}+\mathrm{H}_{2} \times 2$ \\
Anoda: & $\mathrm{OH}^{-} \longrightarrow \mathrm{OH}+\mathrm{e}$ & $\times 4$ \\
& $4 \mathrm{OH}^{\longrightarrow}$ & $2 \mathrm{H}_{2} \mathrm{O}+\mathrm{O}_{2}$ \\
\hline Total & $2 \mathrm{H}_{2} \mathrm{O}$ & $2 \mathrm{H}_{2}+\mathrm{O}_{2}$ \\
& &
\end{tabular}

Dalam proses ini, dihasilkan dua molekul $\mathrm{H}_{2}$ dan satu molekul $\mathrm{O}_{2}$ dalam fasa gas. Hasil elektrolisis tersebut sering dikenal dengan gas Brown. Proses elektrolisis ini berlangsung secara aman dan bersih, serta tidak menghasilkan produk elektrolisis yang berbahaya.

Elektrolisis merupakan proses kimia yang mengubah energi listrik menjadi energi kimia (Shabaan, 1992). Komponen yang terpenting dari proses elektrolisis ini adalah elektroda dan cairan elektrolit. Elektroda yang digunakan pada proses elektrolisis, sebaiknya terbuat dari logam yang tahan terhadap karat.

Selain elektroda, hal yang terpenting juga larutan elektrolit. Larutan asam, basa dan garam biasanya digunakan dalam proses elektrolisis, karena larutan-larutan tersebut dapat dilalui oleh arus listrik sambil menghasilkan partikel-partikel atau ion-ion. Elektrolit tersebut dalam proses elektrolisis berfungsi sebagai media transfer elektron. Elektrolit terdiri atas air murni atau air destilasi dan katalisator. Katalisator akan larut di dalam air murni dan menyatu membentuk larutan elektrolit.

\section{Pengertian Gas Brown}

Gas Brown atau HHO (HirogenHidrogen-Oksigen) merupakan campuran gas hidrogen dan oksigen yang dibuat dengan cara proses elektrolisis air (Ozzie, 2009). Secara umum, elektrolisis air menghasilkan hidrogen di katoda dan oksigen di anoda. Gas-gas ini terperangkap di katoda maupun anoda pada saat yang sama tanpa adanya pemisahan. Pada proses elektrolisis yang dilakukan oleh Yull Brown, tidak menghasilkan gas hidrogen dan air, tetapi menghasilkan campuran gas hidrogen dengan air, yang disebut dengan "Brown gas".

Gas Brown memiliki karakteristik yang berbeda dengan gas-gas lainnya. Yang perlu diperhatikan dari karakteristik gas Brown ini adalah sifat mudah meledak apabila terbakar ${ }^{[2]}$. Oleh sebab itu, gas Brown dikenal memiliki temperatur muai ultra-tinggi. 
Menurut teori klasik, gas Brown adalah campuran gas hidrogen dan oksigen yang dihasilkan dari proses elektrolisis air. Selanjutnya teori mengenai gas Brown ini terus berkembang hingga disetujui sebuah teori yang dapat disesuaikan dengan sifat dan karakteristik gas Brown ini. Teori terbaru dan menjadi patokan mengenai gas Brown menyatakan bahwa dalam proses elektrolisis air menghasilkan 3 jenis gelembung gas yang terdapat pada katoda dan anoda. Selain itu, terdapat molekul gas hidrogen pada katoda dan molekul gas oksigen pada anoda. Gas Brown ini merupakan "gas air" spesial yang merupakan campuran dari gas hidrogen, gas oksigen dan ketiga gelembung gas tersebut ${ }^{[2]}$.

Karakteristik dari gas Brown di antaranya:

- Memiliki kandungan energi yang tinggi dan mampu menghasilkan nyala api dingin (cold flame) dengan potensial energi yang tinggi.

- Mudah dikendalikan, tidak berbau dan tidak berbahaya terhadap tubuh manusia, bahkan apabila terhirup sekalipun.

- Lebih terlihat dibandingkan udara, dan dapat berdifusi dengan udara secara cepat

- Memiliki nilai batas flammability yang tinggi, sehingga lebih aman daripada gas pembakaran yang lainnya.

\section{Elektroliser}

Alat yang digunakan untuk menguraikan air disebut dengan elektroliser ${ }^{[2]}$. Di dalam elektroliser, air $\left(\mathrm{H}_{2} \mathrm{O}\right)$ dipecah menjadi gas $\mathrm{HHO}$ atau sering disebut sebagai Brown gas. Elektroliser juga merupakan istilah lain untuk menyebut generator hidrogen. Elektroliser menghasilkan hidrogen dengan cara mengalirkan arus listrik pada media air. Elektroda akan mengubah struktur atom hidrogen $\left(\mathrm{H}_{2}\right)$ dan oksigen $(\mathrm{O})$ pada air. Selain itu, ikatan neutron yang mengikat partikel $\mathrm{H}$ dan $\mathrm{O}$ akan terlepas, sehingga partikel $\mathrm{H}$ akan tertarik ke elektroda positif dan partikel $\mathrm{O}$ akan tertarik ke elektroda negatif elektroliser ${ }^{[6]}$. Sejalan dengan proses tersebut, volume dan gelembung gas $\mathrm{H}$ dan $\mathrm{O}$ yang melekat pada elektroda akan bertambah, terlepas mengambang, dan kemudian bergerak naik. Saat gelembung gas hidrogen dan oksigen terlepas dari permukaan air, partikel gas tersebut akan berikatan kembali di ruang udara sebagai Brown gas atau gas $\mathrm{HHO}$.

\section{Rancangan Rangkaian Pengendali Elektroliser}

\section{Pengubah Frekuensi ke Tegangan}

Pengubah ini menggunakan IC LM 331 dengan desain khusus sebagai Frequency to Voltage Converter atau pengubah Frekuensi menjadi Tegangan. Dalam penggunaanya, IC LM 331 telah teruji dengan sangat presisi.

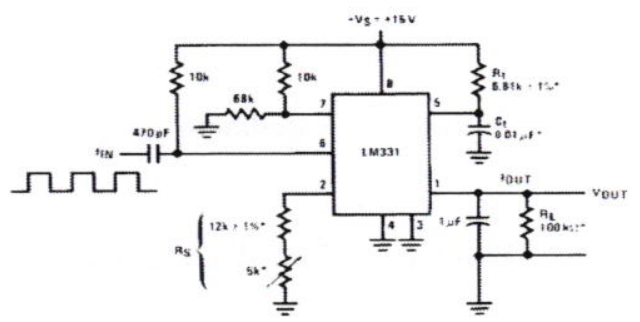

Gambar 2. Rangkaian Frequency to Voltage Converter

Rumusan yang dipakai untuk LM 331 sebagai pengubah frekuensi ke tegangan adalah:

$V_{\text {out }}=f_{\text {in }} \times 2.09 \mathrm{~V} \times \frac{R_{\mathrm{i}}}{R_{s}} \times\left(R_{\mathrm{t}} C_{\mathrm{t}}\right) \ldots(1)$ 
dengan:

$$
\begin{array}{ll}
V_{\text {out }} & =\text { tegangan keluar } \\
f_{\text {in }} & =\text { frekuensi masuk } \\
R & =\text { resistor } \\
C & =\text { kapasitor }
\end{array}
$$

\section{Penguat Non - inverting}

Operational Amplifier, sering disingkat dengan sebutan Op-Amp, merupakan komponen yang penting dalam rangkaian elektronik berdaya rendah (low power). Istilah operational merujuk pada kegunaan op-amp pada rangkaian elektronik yang memberikan operasi aritmetik pada tegangan input (atau arus input) yang diberikan pada rangkaian.

Salah satu fungsi op-amp adalah sebagai penguat non-inverting atau penguat non pembalik. Kegunaan dari penguat non pembalik adalah menguatkan input tegangan yang rendah dengan referensi $\mathrm{V}_{\mathrm{cc}}$. Rangkaian penguat op-amp noninverting dapat dilihat pada Gambar 3 .

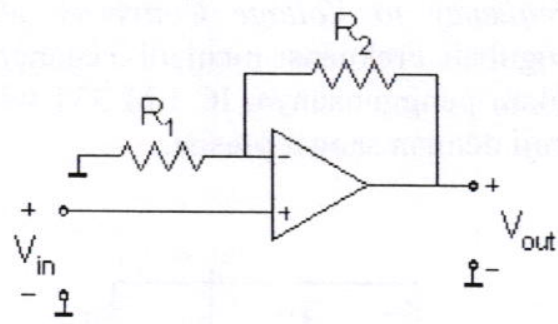

Gambar 3. Rangkaian Penguat

Dari Gambar 3 dihasilkan persamaan berikut:

$$
\begin{aligned}
& V_{\text {out }}=\frac{R_{2}+R_{1}}{R_{1}} \times V_{\text {in }} \\
& V_{\text {out }}=\left(\frac{R_{2}}{R_{1}}+1\right) x V_{\text {in }}
\end{aligned}
$$

dengan :

$V_{\text {out }} \quad=$ Tegangan keluaran
$V_{\text {in }} \quad=$ Tegangan masukan

$R_{1} \quad=$ Resistor 1

$R_{2} \quad=$ Resistor 2

Hasil tegangan output non-inverting ini akan lebih dari satu dan selalu positif.

\section{Modulasi Lebar Pulsa (PWM)}

Modulasi Lebar Pulsa adalah pengaturan lebar pulsa berdasarkan teknik modulasi durasi atau lebar dari waktu tunda positif ataupun waktu tunda negatif pulsa-pulsa persegi. Pada modulasi PWM (Pulse Width Modulation), lebar pulsa pembawa diubah-ubah sesuai dengan besarnya tegangan sinyal pemodulasi. Semakin besar tegangan sinyal pemodulasi (informasi) maka semakin lebar pula pulsa yang dihasilkan. Modulasi PWM juga dikenal sebagai Pulse Duration Modulation (PDM).

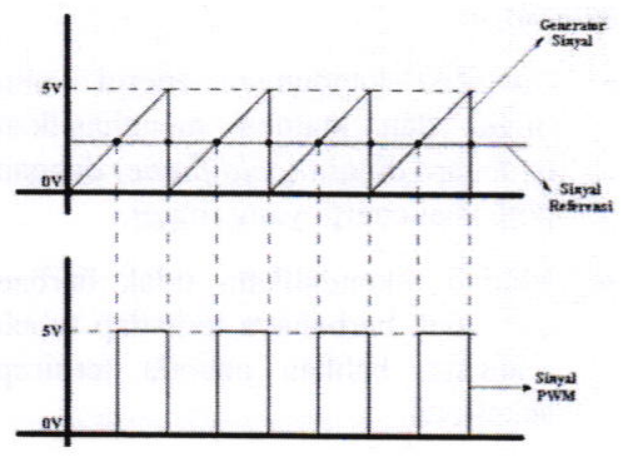

Gambar 4. Signal PWM

Metode $P W M$ digunakan untuk mengatur tegangan keluaran, informasi yang dibawa oleh pulsa-pulsa persegi merupakan tegangan rata-rata. Besarnya tegangan rata-rata tersebut dapat diperoleh dari:

$$
V_{\text {out }}=\frac{\left(V_{\text {ref }} x \text { duty cycle }\right)}{\text { period }}
$$

Semakin lebar durasi waktu tunda positif pulsa dari sinyal PWM yang dihasilkan, maka tegangan semakin tinggi, juga sebaliknya. 


\section{Motor Bensin}

Motor bensin adalah motor bakar torak yang menggunakan percikan api sebagai pemicu atau spark ignition untuk proses pembakarannya. Motor bensin biasanya menggunakan bahan bakar minyak gasoline atau bensin sebagai bahan bakar utamanya. Prinsip kerja motor bakar bensin sesuai dengan Siklus Otto (Gambar 5).

Pada grafik P-v:

- $\quad$ a-2-1-b: kerja masuk

- a-3-4-b: kerja keluar

Pada grafik T-s:

- b-2-3-a: panas masuk

- b-1-4-a: panas keluar
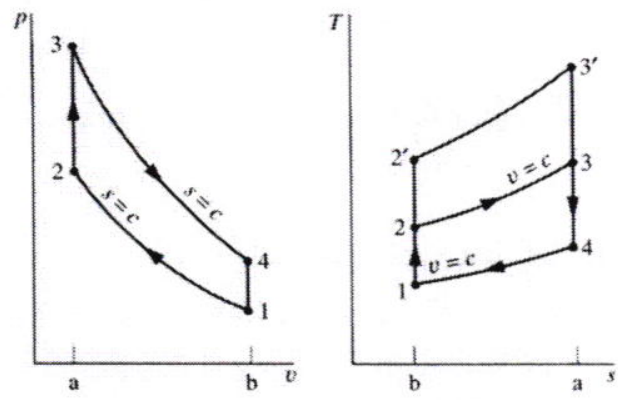

Gambar 5. Siklus Otto

Proses-proses pada Siklus Otto (2s2v):

1-2: Proses tekan (isentropik):

$$
\mathrm{Q}_{12}=0, W_{12}=m\left(u_{2}-u_{1}\right)
$$

2-3: Proses pemasukan panas (isokhorik): $\quad W_{23}=0$, $Q_{23}=m\left(u_{3}-u_{2}\right)$

3-4: Proses ekspansi (isentropik):

$$
Q_{34}=0, W_{34}=m\left(u_{3}-u_{4}\right)
$$

4-1: Proses pembuangan panas (isokhorik):

$$
W_{41}=0, Q_{41}=m\left(u_{4}-u_{1}\right)
$$

\section{Kinerja Motor Bakar}

Kinerja motor bensin dapat diketahui melalui beberapa parameter, antara lain:

a. Daya poros $(\mathrm{Ne})$

Daya poros adalah daya yang dimanfaatkan pada motor bakar torak untuk menggerakan beban. Daya poros dapat dihitung:

$$
N e=\frac{2 \times \pi \times N_{d} \times T}{60}(\text { Watt })
$$

dimana:

$$
\begin{array}{ll}
N_{e} & =\text { Daya Poros (W) } \\
T & =\text { Torsi (N.m) } \\
N_{d} & =\text { Putaran Motor (Rpm) }
\end{array}
$$

(sumber: A wiranto, 1988)

$$
\text { b. Konsumsi bahan bakar }
$$

Konsumsi bahan bakar spesifik adalah indikator unjuk kerja dari suatu mesin termal yang berhubungan langsung dengan nilai ekonomisnya, karena dengan diketahuinya Sfc maka dapat dihitung jumlah bahan bakar yang dibutuhkan pada selang waktu tertentu untuk menghasilkan sejumlah daya.

$$
S f c=\frac{m_{f} x 10^{3}}{N_{\theta}} \ldots(10)
$$

Dimana:

Sfc = konsumsi bahan bakar spesifik (g/kW.h)

$m_{f}=$ laju aliran bahan bakar (kg/jam)

$N_{\theta} \quad=$ Daya Poros (W)

Dengan besarnya laju aliran bahan bakar $\left(m_{f}\right)$ dihitung menggunakan persamaan berikut: 
$m_{f}=\frac{s_{g f} \times V_{f} \times 10^{-s}}{t_{f}} \times 3600$

dimana:

$S g_{f} \quad=$ Kerapatan bahan bakar

$V_{f} \quad=$ Volume bahan bakar $(\mathrm{ml})$

$t_{f} \quad=$ Waktu yang diperlukan untuk menghabiskan bahan bakar (detik)

(sumber: A wiranto, 1988)

\section{c. Efisiensi Thermal}

Kerja berguna yang dihasilkan selalu lebih kecil besarnya dibandingkan energi yang dihasilkan poros engkol karena adanya rugi-rugi mekanis yang timbul ketika poros engkol mulai bekerja. Efisiensi ini sering disebut efisiensi termal. Dengan alasan ekonomis perlu dicari kerja maksimum yang dapat dihasilkan dari pembakaran sejumlah bahan bakar.

$\eta_{t h}=\frac{N e}{m f \times L H V} \times 100 \%$

dimana:

LHV = nilai kalor bawah bahan bakar $(\mathrm{kj} / \mathrm{kg})$

$m_{f} \quad$ = laju aliran bahan bakar $(\mathrm{kg} / \mathrm{jam})$

(sumber: A wiranto, 1988)

\section{Diagram Alir Penelitian}

Diagram alir penelitian diperlihatkan pada Gambar 6.

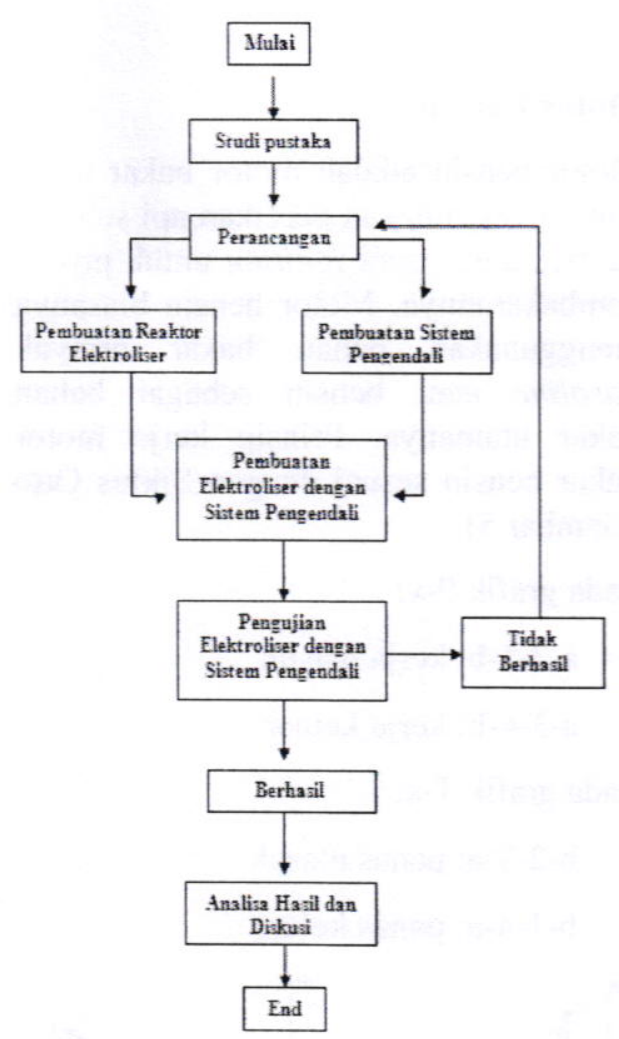

Gambar 6. Diagram Alir Penelitian

\section{HASIL DAN PEMBAHASAN}

Sistem elektroliser dengan pengendali laju produksi adalah sistem penambahan gas HHO pada mesin bensin. Penambahan gas $\mathrm{HHO}$ tersebut dikendalikan oleh rangkaian kontrol laju produksi gas yang disesuaikan dengan kecepatan putaran mesin.

\section{Prinsip Kerja Alat}

Prinsip alat kerja elekroliser dengan sistem pengendali laju produksi secara umum adalah dengan mengendalikan proses produksi gas $\mathrm{HHO}$ berdasarkan kecepatan putaran mesin. Putaran mesin dapat diindentifikasi melalui distributor yang berupa letupan, sehingga frekuensi diubah menjadi tegangan melalui rangkaian $F$ to $V$ (IC LM 331). Karena keluaran dari rangkaian $F$ to $V$ sangat kecil, tegangan keluaran tersebut diperkuat melalui rangkaian penguat 
operasional (IC LM 741), sehingga tegangan keluaran dari LM 741 hampir $12 \mathrm{~V}$ pada kecepatan putar mesin 3000 rpm. Pada saat kecepatan mesin 3000 rpm tegangan sekitar $12 \mathrm{~V}$ (berdasarkan batasan masalah, kecepatan paling tinggi adalah pada $3000 \mathrm{rpm}$ ). Setelah tegangan keluar dari rangkaian penguat, kemudian dikoneksikan ke rangkaian modulasi lebar pulsa (PWM) dan tabung elektroliser untuk membuat gaya tarik (stress force) untuk memecahkan air menjadi gas $\mathrm{HHO}$. Gas $\mathrm{HHO}$ yang dihasilkan, masuk ke sistem karburator mesin bensin agar tercampur homogen dengan bahan bakar bensin, sehingga secara keseluruhan gas produksi hasil elektrolisis dikendalikan berdasarkan putaran mesin.

Tabel 1. Spesifikasi Mesin Bensin yang Digunakan

\begin{tabular}{|c|c|}
\hline Jenis: & $\begin{array}{l}\text { Motor Bensin } \\
\text { Empat Langkah }\end{array}$ \\
\hline Pabrik: & Ford, USA \\
\hline Mesin: & $2271 \mathrm{E}$ \\
\hline Tipe: & $\begin{array}{l}\text { Empat Silinder } \\
\text { Dengan silinder } \\
\text { sebaris (in line) }\end{array}$ \\
\hline $\begin{array}{l}\text { Diameter } \\
\text { Silinder: }\end{array}$ & $80.98 \mathrm{~mm}$ \\
\hline $\begin{array}{l}\text { Panjang Langkah } \\
\text { Torak: }\end{array}$ & $53.29 \mathrm{~mm}$ \\
\hline Volume Silinder: & $1.098 \mathrm{cc}$ \\
\hline Rasio Kompresi: & $\begin{array}{l}8: 1 \text { (low); 9:1 } \\
\text { (high) }\end{array}$ \\
\hline Firing order: & $1-2-4-3$ \\
\hline Celah Katup: & $\begin{array}{l}\text { Inlet } 0.2 \mathrm{~mm} \text {; } \\
\text { outlet } 0.56 \mathrm{~mm}\end{array}$ \\
\hline \multicolumn{2}{|l|}{ Sistem Bahan Bakar: } \\
\hline Bahan Bakar: & $\begin{array}{l}91 \text { oktana (RM) } \\
\text { gasoline (Lc);97 } \\
\text { oktana } \\
\text { (RM)gasoline (Hc) }\end{array}$ \\
\hline Karburator: & Down Draugh \\
\hline
\end{tabular}

\section{HASIL DAN DISKUSI}

Pengujian yang dilakukan bertujuan untuk mengetahui laju produksi gas HHO yang dikendalikan oleh kecepatan putaran mesin yang hasil gas tersebut diaplikasikan untuk penambahan bahan bakar mesin bensin dan pengaruhnya terhadap unjuk kerja mesin bensin.

Untuk mendapatkan proporsi jumlah gas HHO yang diinginkan maka terlebih dahulu dilakukan pengujian hubungan kebutuhan bahan bakar terhadap putaran mesin. Dari data tersebut dapat diamati bahwa konsumsi bahan bakar tergantung pada nilai rpm dan beban kendaraan. Dengan menggunakan hasil rata-ratanya, maka dapat dihitung laju tambahan gas $\mathrm{HHO}$ yang diinginkan berdasarkan nilai kecepatannya.

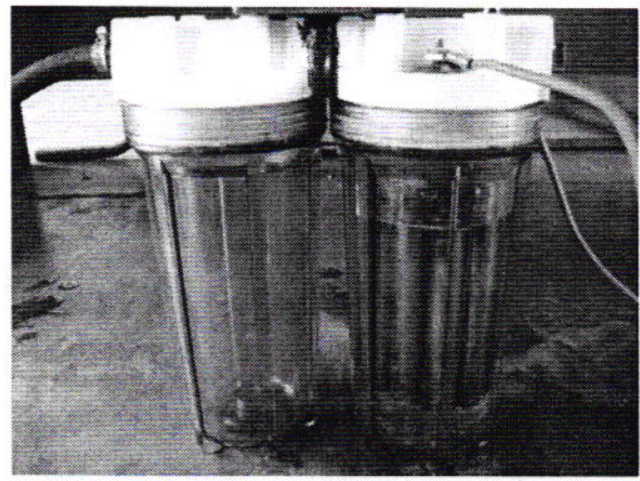

Gambar 7. Tabung Elektroliser

Dari percobaan kecepatan putaran mesin didapatkan frekuensi yang akan diubah menjadi tegangan sebesar yang tertera pada Tabel 1.

Tabel 2. Tegangan Hasil Pengubahan F to $\mathrm{V}$

\begin{tabular}{cccc} 
No. & $\begin{array}{c}\text { Putaran } \\
\text { (RPM) }\end{array}$ & $\begin{array}{c}\text { Frekuensi } \\
\text { (Hz) }\end{array}$ & $\begin{array}{c}\text { Tegangan } \\
(\mathbf{V})\end{array}$ \\
\hline 1. & 1020 & 320 & 8.10 \\
2. & 1560 & 530 & 8.20 \\
3. & 2003 & 731 & 9.30 \\
4. & 2505 & 927 & 10.80 \\
5. & 2998 & 1,090 & 11.30
\end{tabular}

Tegangan yang didapat dari pengubahan Frekuensi to Voltage berubah tergantung 
dari putaran mesin yang dijalankan, akan tetapi tegangan yang dihasilkan masih kecil, yaitu antara $1-3.3$ Volt. Tegangan keluaran dari rangkaian $F$ to $V$ tersebut dikuatkan oleh penguat noninverting. Penguatan tersebut menghasilkan tegangan sebesar 8.10 11.30 Volt. Tegangan tersebut merupakan batas bawah dan batas atas tegangan jenuh.

Hasil yang didapatkan dari pengendalian putaran mesin bensin terhadap laju produksi gas HHO (Gambar 8) adalah saat putaran mesin naik dibutuhkan laju produksi yang cenderung meningkat pula.

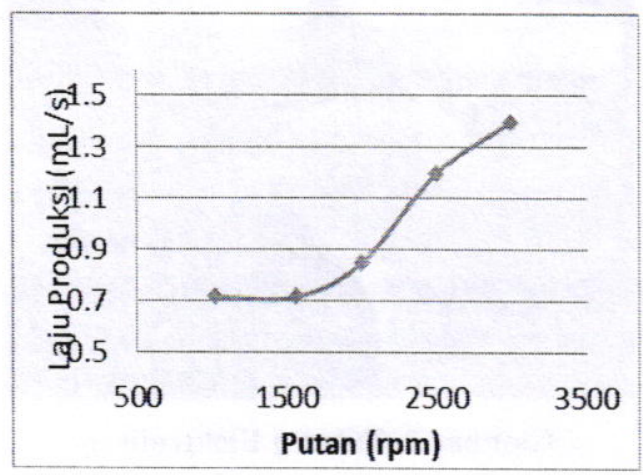

Gambar 8. Grafik Laju Produksi Gas terhadap Putaran

Grafik tersebut menunjukkan bahwa semakin naik putaran mesin, maka dibutuhkan laju produksi gas yang semakin besar pula. Saat kecepatan putaran mesin sebelum $1500 \mathrm{rpm}$ laju gas yang dibutuhkan bergerak konstan.

Setelah didapat gas hasil elektroliser yang laju produksinya dikendalikan oleh kecepatan putaran mesin kemudian gas diaplikasikan untuk penambahan bahan bakar mesin bensin, unjuk kerja mesin bensin diharapkan semakin baik. Unjuk kerja tersebut ditandai oleh torsi menjadi naik ketika ditambahkan gas hasil elektrolisis, dan Specific Fuel Consumption semakin kecil. Semakin kecil SFC maka penghematan bahan bakar semakin baik, efisiensi termal motor bensin semakin meningkat, dan kandungan gas buang yang dihasilkan saat penambahan gas $\mathrm{HHO}$ untuk motor bensin semakin baik.

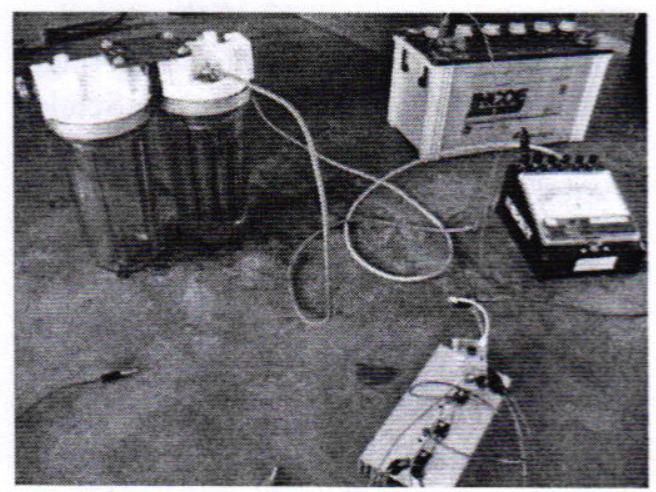

Gambar 9 Rangkaian Sistem Elektroliser dengan Sistem Pengendali

\section{KESIMPULAN}

Dari pembahasan di atas dapat disimpulkan sebagai berikut:

1. Frekuensi putaran mesin semakin meningkat saat putaran mesin mengalami peningkatan.

2. Saat putaran mesin naik dan frekuensi naik, maka jumlah tegangan yang dihasilkan dari pengkonversian frekuensi ke tegangan semakin meningkat, akan tetapi peningkatannya masih sedikit.

3. Tegangan keluaran dari rangkaian $F$ to $V$ dikuatkan oleh rangkaian penguat non-inverting, penguatan tersebut jenuh minimum pada 8.10 Volt dan tegangan jenuh maksimum sebesar 11.30 Volt.

4. Laju produksi gas hasil elektrolisis air dapat dikendalikan oleh putaran mesin. Pada saat putaran mesin $1000 \mathrm{rpm}$ laju produksinya 0.72 $\mathrm{mL} / \mathrm{s}$ dan saat putaran mesin 3000 rpm laju produksinya $1.4 \mathrm{~mL} / \mathrm{s}$.

5. Gas hasil elektrolisis air yang dikendalikan oleh putaran mesin bensin tersebut diaplikasikan untuk penambahan bahan bakar bensin dan 
diharapkan gas tersebut dapat meningkatkan unjuk kerja mesin bensin dan mengurangi emisi gas buang mesin bensin.

\section{DAFTAR PUSTAKA}

1. Christopher J. Chadwell \& Philip J. G. Dingle. 2008. Effect of Diesel and Water Co-injection with Real-Time Control on Diesel Engine Performance and Emissions. Michigan: Southwest Research Institute.

2. Freedom, Ozie. 2010. Water4gas. Kanada: Water4gas.com.

3. Kelly, Pattrick. J. A Practical Guide to Free Energy Device Chapter 10: Automotive System.

4. LG, Harus. 2010. Pengembangan Elektroliser Gas HHO dengan Sistem Pengendali Laju. Surabaya: Jurusan Teknik Mesin, Fakultas Teknologi Industri, ITS.

5. Prof. M. Kanarev. Low Current Process for Elektrolisis.

6. Meyer, Stanley A. 1995. Water Fuel Cell. Ohio: Grove City.

7. Rasiawan. 2010. Design and Manufacturing Elektronics Control of Brown Gas Electrolyser Sistem. Surabaya: Jurusan Teknik Mesin, ITS.

8. Wall, Jacob. 2008. Effect of Hydrogen Enriched Hydrocarbon Combustion on Emissions and Performance. Idaho: Department of Biological and Agricultural Engineering. University of Idaho. 